Vergelijkt men de werkelijke vaste kosten met $1 / 12$ van de begroote jaarlijksche vaste kosten, dan blijkt:

1. dat in totaal $f 500$. - meer is uitgegeven, hetgeen wijst op een vergrooting van de bedrijfscapaciteit;

2. dat dit met name het geval is bij de leiding van de fabricage-afdeeling en bij het productiebureau.

Hier moet het roode sein geheschen worden.

Verder blijkt dat, wat betreft de wisselende kosten, men aanzienlijk over de schreef, i.c. het budget, is gegaan Heel duidelijk is dit bij de post Reparatie en onderhoud. Volgens de oude methode bedraagt de dekking nog iets meer dan de werkelijke kosten. Het vaste kostenelement blijft constant, terwijl de wisselende kosten meer dan proportioneel stijgen. Dit kan te verklaren zijn uit het feit, dat de machines overbelast zijn en extra-onderhoud vergen.

Uit dit voorbeeld blijkt, dat men het verloop van kosten bij stijgende productie terdege in het oog moet houden. De voordeelige saldi van de vaste kostenelementen en dekkingen er voor uit hoofde van de overbezetting dienen gereserveerd te worden om t.z.t. gecompenseerd te worden met onderbezettingsverliezen op deze vaste kostenelementen.

\title{
WETTELIJKE REGELING VAN HET ACCOUNTANTSBEROEP IN ENGELAND
}

\author{
door A. F. Lafeber.
}

De na-oorlogsche nummers van het MAB hebben weer in enkele artikelen de aandacht van de lezers gevraagd voor de kwestie, die het Nederlandsch Instituut van Accountants reeds sedert het begin van zijn oprichting bezighoudt, t.w. de wettelijke regeling van het accountantsberoep. Waar wij als Nederlanders er zeker niet afkeerig van zijn eens te zien hoe anderen een probleem aanpakken, waarmede wij zelf moeite hebben, zal het den lezers wellicht interesseeren hoe in Engeland de stand van zaken is t.o.v. de wettelijke regeling.

In ..The Accountant" van 1 Juni j.l. wordt medegedeeld, dat vele en langdurige besprekingen van afgevaardigden van diverse vooraanstaande accountantsorganisaties hebben geleid tot de samenstelling van een wetsontwerp, dat, indien de leden van deze organisaties en het Parlement er hun goedkeuring aan kunnen hechten, bekend zal staan als de „Public Accountants Bill 1946".

Als reden voor de opstelling van dit ontwerp wordt aangegeven, dat het wenschelijk is het hcoge peil van het beroep. dat door het meerendeel van de accountants wordt gehandhaafd, algemeen doorgevoerd te krijgen, waarmede de belangen van het publiek en de accountants beiden gebaat zullen zijn. De achting. welke het publiek nu vo רr den accountant heeft, mag niet worden verspild door practijken van lieden, die niet in staat zijn de diensten, die zij aan'ieden, behoorlijk uit te voeren.

Het valt reeds direct op, dat de wet alleen betrekking zal hebben op public accountants. Dit wordt ook duidelijk in het wetsontwerp omschreven. Als public accountant wordt aangemerkt hij, die een .,public-accountancy-practijk" uitoefent. (waarbij dan .,public accountancy" weer omschreven is met: de opstelling, investigation, controle en certificeering van balansen, verlies- en winstrekeningen, opstellingen van inkomsten en uitgaven of andere soortgelijke rekeningen of een of meer van dergelijke

m a b blz. 358 
functies) en die in verband hiermede zijn diensten aan het publiek aanbiedt tegen belooning.

Alleen deze personen verkrijgen de door de wet beschermde titel van .public accountant" (mits zij nog aan eenige hierna te noemen eischen voldoen) en alleen zij mogen de ,public accountancy" beoefenen. Uitzondering is gemaakt voor die menschen, die "public accountancy" beoefenen als onderdeel van hun hoofdbezigheid. $Z_{i j}$ vallen verder buiten dit wetsontwerp, mits zij zich niet als public accountant uitgeven. Accountants uit het buitenland, die incidenteel werk in Engeland uitoefenen zonder aldaar gevestigd te zijn, worden eveneens ongemoeid gelaten. Opmerkenswaard is, dat ook de gespecialiseerde accountants niet onder dit wetsontwerp vallen. Voorzoover zij georganiseerd zijn in het „Institute of Municipal Treasurers and Accountants" of het "Institute of Costs and Works Accountants" mogen zij hun bezigheden voortzetten (indien zij zich tenminste beperken tot hun speciale adviseerende taak).

Het wetsontwerp gaat uit van de handhaving van de bestaande accountantsorganisaties. Voor de wettelijke regeling worden hiernaast dan ingesteld twee "Public Accountants Councils" t.w. één voor Engeland en Wales en één voor Schotland. Beide functionneeren op gelijke wijze. De Raad voor Engeland en Wales zal bestaan uit 24 leden, waarvan er twintig benoemd worden uit met name genoemde bestaande accountantsvereenigingen, ${ }^{1)}$ één door den Schotschen Raad (voor onderling contact) en drie door den Privy-Council (min of meer te vergelijken met onzen Raad van State, dus: de Regeering). Van deze drie moeten er twee nietaccountant zijn. $Z_{i j}$ hebben de belangen van het publiek te behartigen. De derde is wel accountant en vertegenwoordigt de niet bij de met name genoemde accountantsvereenigingen aangesloten accountants.

De werkzaamheden van den Public Accountants Council zijn velerlei. Genoemd worden o.a contact met overheidsinstanties voor zaken, die voor het accountantswezen van belang zijn, het aanmoedigen van onderzoekingen in accountancy, het uitreiken van beurzen voor studenten in public accountancy. Voor de bescherming van het beroep zijn echter twee dingen van het meeste belang: de inrichting en bijwerking van een .lijst van Public Accountants" en van een ,,register van erkende vereenigingen". Op de liist van erkende vereenigingen komen naast de reeds in de wet opgesomde organisaties ${ }^{1}$ ) (welke alle een goeden naam in Engeland hebben verworven) die vereenigingen, die hiertoe den wensch te kennen geven en waarvan de Public Accountants Council heeft vastgesteld, dat zij zich minstens op hetzelfde peil bewegen als de met name genoemde organisaties. Blijkt later een vereeniging weer beneden het vereischte peil te zakken dan kan zij worden geschrapt. Het belang van inschrijving als erkende vereeniging moge hieronder blijken. Opgemerkt moet nog worden, dat ook buitenlandsche vereenigingen erkend kunnen worden.

De lijst van public accountants vormt de kern van het wetsontwerp. Immers alleen wie hierop geplaatst zijn zullen zich de titel van public accountant mogen eigen maken en de public accountancy mogen uitoefe-

1) Dit zijn: Institute of Chartered Accountants in England and Wales (met 10 leden in den Raad). Society of Incorporated Accountants and Auditors (5). Association of Cortified and Corporate Accountants (4). Society of Accountants in Edinburgh, Institute of Accountants and Actuaries in Glasgow, Society of Accountants in Aberdeen (gezamenlijk 1).

In den Schotschen Raad worden opgenomen: Sociecy of Accountants in Edinburgh (4). Institute of Accountants and Actuaries in Glasgow (5). Society of Accountants in Aberdeen (1). Society of Incorporated Accountants and Auditors (1). Association of Certifled and Corporate Accountants (2). 
nen. Om op deze lijst geplaatst te kunnen worden moet aan verschillende eischen zijn voldaan.

Voor de eerste opstelling (dus als overgangsmaatregel) gelden de volgende bepalingen: Leden van erkende vereenigingen zullen aan den Public Accountants Council aannemelijk moeten maken: 1e) dat zij van plan zijn de accountantspractijk binnen het gebied van den Raad uit te oefenen; 2e) dat zij op den dag van het opstellen van de lijst of gedurende 12 maanden daarvoor practijk utoefenden of vroeger gedurende vijf opeenvolgende jaren hebben uitgeoefend. Niet ieder lid van een erkende vereeniging zal dus als ,public accountant" worden ingeschreven: interne accountants enz, vallen er buiten. Accountants, die niet als lid van een erkende vereeniging zijn ingeschreven, zullen, behalve aan de genoemde, ook nog aan de volgende eischen moeten voldoen: dat zij te goeder naam en faam bekend staan, terwijl in elk geval voor hen een periode van vijf achtereenvolgende jaren practijk voorgeschreven is.

Een candidaat, die na de eerste opstelling van de lijst als public accountant wil worden ingeschreven zal aan de volgende vereischten moeten voldoen. 1e) aannemelijk maken, dat hij van plan is als public accountant practijk uit te oefenen binnen het gebied van den public accountants council; $2 e$ ) indien hij lid is van een erkende vereeniging: dat hij gewerkt heeft bij een accountant-lid van een erkende vereeniging gedurende minstens $2 \frac{1}{2}$ jaar; indien hij geen lid is van een erkende vereeniging: dat hij een goede reputatie geniet, over voldoende vakkennis beschikt en in accountancy werkzaam is geweest gedurende minstens 9 jaar. Alleen in dit laatste geval (dus bij toelating niet-leden van een erkende vereeniging) kan de Public Accountants Council examens afnemen om de vakkennis te toetsen. Overigens blijft de regeling van examens volledig in handen van de bestaande vereenigingen.

Bepaalde uitzonderingen kunnen voor de inschrijvingen op de lijst worden toegestaan. Aangeteekend mag wel worden, dat voor hen, wier loopbaan door militairen dienst is onderbroken, de bovengenoemde termijnen worden ingekort.

De wettelijke regeling zal een ontwikkeling stimuleeren, waarbij op den langen duur vrijwel uitsluitend leden van erkende organisaties als public accountant naar voren komen. Aan het bestaan van deze organi-

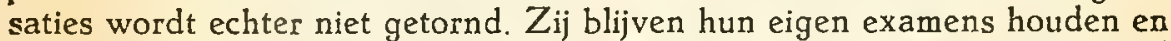
handhaven ook zelf hun tuchtrechtspraak. Het geschrapt worden als lid van een erkende vereeniging beteekent tevens royement als public accountant. Wel zal de Public Accountants Council toezien, dat alle organisaties zich op een behoorlijk peil blijven bewegen. Ongeacht de bepalingen in het wetsontwerp zullen hier trouwens de groote vereenigingen, die door hun relatief groote afvaardiging in den Public Accountants Council een belangrijken invloed hebben, wel voor zorgen.

In het bovenstaande werden slechts de belangrijkste bepalingen uit het Engelsche wetsontwerp aangeroerd. Wellicht kan dit ontwerp bif onze overwegingen voor de wettelijke regeling van het accountantsberoep in Nederland nog goede diensten bewijzen. 